\title{
Characterisation of heart rate response to exercise in the sick sinus syndrome ${ }^{1,2}$
}

\author{
WILLIAM HOLDEN, JOHN H. MCANULTY, AND SHAHBUDIN H. RAHIMTOOLA
}

From the Division of Cardiology, Department of Medicine, University of Oregon Health Sciences Center, Portland, Oregon, U.S.A.

SUMMARY Patients with sick sinus syndrome have abnormalities of the sinoatrial node. We have measured the heart rate response to exercise in 7 patients with sick sinus syndrome without significant associated heart disease (group A) mean age 53.4 years, and compared this with 7 'normal' patients who were age-matched to within 5 years (group B), and 7 younger, well-trained subjects (group C). All underwent maximal treadmill exercise.

Although maximum oxygen consumption $\left(\mathrm{V}_{2} \max \right), 1 / \min$ per $\mathrm{kg}$, in group A was not significantly different from group $B(23.8 \pm 4.7$ vs $19.9 \pm 0.8$, mean \pm SE) maximum heart rate, beats $/ \mathrm{min}$, in group A was significantly lower than in group B $(124 \pm 8.9$ vs $163 \pm 3.7, \mathrm{P}<0.001)$. At the end of 3 minutes of Bruce Stage I exercise, group A patients had a heart rate $<130 /$ minute $(95 \%$ confidence level), whereas group B patients had heart rates $>134 /$ minute.

$\dot{\mathrm{VO}}_{2}$ was plotted against heart rate (HR). Patients in group A had a significantly lower slope $(\Delta \mathrm{HR} 5 \cdot 20$ $\pm 0.33 / \Delta 1 \mathrm{ml} \mathrm{VO}{ }_{2} / \mathrm{kg}$ per min, $\left.\mathrm{P}<0.001\right)$. There was no significant difference in the slopes between groups $\mathrm{A}$ and $\mathrm{C}$.

On exercise patients with sick sinus syndrome have a normal $\mathrm{VO}_{2}$, but a reduced heart rate response as compared with age-matched normal patients. This abnormal heart rate response to the physiological stimulus of exercise may be of help in the evaluation of patients with sick sinus syndrome who do not have significant underlying heart disease.

Diseases of the sinoatrial node can present in a variety of clinical patterns including persistent bradycardia, sinus arrest, and sinoatrial node exit block (Ferrer, 1968, 1973). In some patients, the bradycardia alternates with tachyarrhythmias, the 'bradycardia-tachycardia' syndrome (Short, 1954; Kaplan et al., 1973). All of these patterns are known collectively as the 'sick sinus syndrome'. Previous studies of patients with the sick sinus syndrome have assessed the function of the sinus node at rest, with atrial pacing, and with isoprenaline infusion (Ferrer, 1968; Rosen et al., 1971; Mandel et al., 1972; Ferrer, 1973; Strauss et al., 1973; Mandel et al., 1975; Benditt et al., 1976). We have studied the heart rate response to maximum exercise and found

'Supported in part by a Program Project Grant from the National Heart, Lung and Blood Institute, Bethesda, Maryland, and by a grant from the Oregon Heart Association.

${ }^{2}$ Presented in part at the Annual Scientific Sessions of the American Heart Association, Miami, Florida, November 1976.

Received for publication 14 November 1977 it to be reduced when compared with age-matched controls.

\section{Subjects and methods}

Twenty-one patients underwent exercise stress testing in the electrocardiographic laboratory of the University of Oregon Health Sciences Center. The subjects were divided into three groups: group A7 patients with sick sinus syndrome; group B7 controls who were age-matched to within 5 years; and group $\mathrm{C}-7$ younger, trained individuals.

Of the group A patients, 5 were men and 2 were women. Their mean age was 53.4 years. They fulfilled at least one of the following predetermined criteria for entry into the study: (a) unexplained, persistent bradycardia (less than 50 beats/minute) in the resting electrocardiogram; (b) prolonged sinoatrial node pauses (greater than 2 seconds); (c) sinoatrial node exit block; (d) sinoatrial node arrest with pauses longer than 2 seconds after conversion of 
tachycardia. The clinical, electrocardiographic, and electrophysiological characteristics of group A patients are presented in Table 1 . Of the 7 patients, 5 had symptoms referable to the sick sinus syndrome, and all patients who had electrophysiological studies had a prolonged sinus node recovery time (Dhingra et al., 1973) or a prolonged secondary pause after termination of atrial pacing (Benditt et al., 1976). One patient had a demand pacemaker inserted one year before this study and 2 others received demand pacemakers after our examination. One symptomatic patient improved with oral atropine and quinidine and was not given a pacemaker by his doctor. The other symptomatic patient complained of weakness and dizziness but his symptoms were not considered severe or frequent enough for treatment. Five of the group A patients were Functional Class I by the New York Heart Association Classification (1973), the other 2 patients were Functional Class II. Case 4 was a teacher and a coach who trained regularly by jogging and playing basketball. Associated cardiovascular disorders were present in only 2 patients; one had a history of hypertension and a history of previous subendocardial myocardial infarction (case 3 ) which was not documented, and the other (case 2) had a previous myocardial infarction which was diagnosed by chest pain and typical enzyme changes but without electrocardiographic abnormality.

Three group B subjects were men and 4 were women. Their mean age was $56 \cdot 0$ years. They were volunteers from the hospital staff or were patients referred to the electrocardiographic laboratory for an exercise stress test. All patients in group B had normal resting electrocardiograms and negative stress tests for myocardial ischaemia and had no clinical evidence of heart disease.

Group C consisted of 7 volunteer subjects, 6 men and 1 woman, all of whom jogged regularly and several of whom climbed mountains frequently. Their mean age was 33.4 years. Most of them were doctors.

Before exercise all subjects underwent a resting electrocardiogram and patients in groups $\mathrm{A}$ and $\mathrm{B}$ received a physical examination. Special attention was given to screening for evidence of conditions that might limit exercise capability, such as pulmonary, musculoskeletal, or neurological disorders. No patient was taking cardiac drugs. Three patients in group $A$ and one in group $B$ were taking noncardiac drugs which were discontinued at least 24 hours before the test. Informed consent was obtained from each subject.

The treadmill exercise procedure was chosen on the basis of the patient's age and functional ability; younger patients underwent the standard Bruce procedure (Bruce et al., 1973) and the older subjects a procedure modified from the standard Bruce as follows (Table 2) (National Council of the YMCA, 1975).

Table 1 Clinical, electrocardiographic, and electrophysiological findings in sick sinus syndrome (group $A$ ) patients

\begin{tabular}{|c|c|c|c|c|c|c|c|c|}
\hline \multirow{2}{*}{$\begin{array}{l}\text { Case } \\
\text { no. }\end{array}$} & \multirow{2}{*}{$\begin{array}{l}\text { Presenting } \\
\text { symptoms }\end{array}$} & \multirow{2}{*}{$\begin{array}{l}\text { Electrocardiographic } \\
\text { findings }\end{array}$} & \multicolumn{5}{|c|}{ Electrophysiological studies } & \multirow{2}{*}{$\begin{array}{l}\text { Holter monitor } \\
\text { findings }\end{array}$} \\
\hline & & & $\begin{array}{l}A H^{\star} \\
(m s)\end{array}$ & $\begin{array}{l}H V \dagger \\
(m s)\end{array}$ & $\begin{array}{l}\text { Atrial } \\
\text { paced rate } \\
\text { (beats/min) }\end{array}$ & $\begin{array}{l}\text { SNRT } \\
(m s)\end{array}$ & $\begin{array}{l}\text { Longest } R R \\
\text { interval } \\
\text { ( } m s)\end{array}$ & \\
\hline 1 & $\begin{array}{r}\text { Dizziness, } \\
\text { syncope }\end{array}$ & $\begin{array}{l}\text { Sinus arrhythmia, } \\
\text { first degree AV block }\end{array}$ & 64 & 62 & 110 & 1170 & 10075 & Not done \\
\hline 2 & None & $\begin{array}{l}\text { Left axis deviation, } \\
\text { sinus bradycardia }\end{array}$ & & & & Not done & & $\begin{array}{l}\text { Bradycardia } \\
\quad \text { (low of } 36) \\
\text { sinus pauses }(>2 s)\end{array}$ \\
\hline 3 & $\begin{array}{r}\text { Dizziness, } \\
\text { syncope }\end{array}$ & Sinus bradycardia & 90 & 45 & 110 & 1500 & 1580 & $\begin{array}{l}\text { Bradycardia } \\
\quad \text { (low of 40) } \\
\text { PVC's }\end{array}$ \\
\hline 4 & $\begin{array}{r}\text { Palpitation, } \\
\text { dizziness }\end{array}$ & $\begin{array}{l}\text { Sinus bradycardia, } \\
\text { sinus pauses }(>2 s)\end{array}$ & 84 & 73 & 90 & 3480 & 3480 & $\begin{array}{l}\text { Bradycardia } \\
\quad(\text { low of } 40) \\
\text { sinus pauses }(>2 s)\end{array}$ \\
\hline 5 & $\begin{array}{l}\text { Dizziness, } \\
\text { weakness }\end{array}$ & $\begin{array}{l}\text { Sinus bradycardia, } \\
\text { left ventricular } \\
\text { hypertrophy }\end{array}$ & 105 & 40 & 130 & 1680 & 1680 & Not done \\
\hline 6 & None & $\begin{array}{l}\text { Sinus bradycardia of } \\
35 \text { beats/min, first } \\
\text { degree AV block }\end{array}$ & & & & Not done & & Not done \\
\hline 7 & Syncope & Sinus bradycardia & 106 & 43 & 110 & 1468 & 1468 & $\begin{array}{c}\text { Bradycardia } \\
\quad \text { (low of } 37) \\
\text { sinus pauses } \\
(>1.5 \mathrm{~s})\end{array}$ \\
\hline
\end{tabular}

$\star A H=$ Time from atrial depolarisation to His bundle depolarisation.

†HV $=$ Time from His bundle depolarisation to QRS of electrocardiogram.

¥SNRT $=$ Sinus node recovery time after cessation of atrial pacing. 
Table 2 Exercise procedures

\begin{tabular}{|c|c|c|c|c|}
\hline \multirow[t]{2}{*}{ Stage } & \multicolumn{2}{|l|}{ Bruce } & \multicolumn{2}{|c|}{ Modified Bruce } \\
\hline & Grade & $m p h$ & Grade & $m p h$ \\
\hline $\begin{array}{l}\text { I } \\
\text { II } \\
\text { III } \\
\text { IV } \\
\text { V } \\
\text { VI } \\
\text { VII }\end{array}$ & $\begin{array}{l}10 \% \\
12 \% \\
14 \% \\
16 \% \\
18 \% \\
20 \% \\
22 \%\end{array}$ & $\begin{array}{l}1 \cdot 7 \\
2.5 \\
3.4 \\
4 \cdot 2 \\
5.0 \\
5.5 \\
6.0\end{array}$ & $\begin{array}{r}0 \% \\
7.0 \% \\
7.5 \% \\
12.5 \% \\
14.0 \% \\
18.0 \% \\
22.0 \%\end{array}$ & $\begin{array}{l}2 \cdot 0 \\
2 \cdot 0 \\
3 \cdot 0 \\
3 \cdot 0 \\
3 \cdot 4 \\
3 \cdot 4 \\
3 \cdot 4\end{array}$ \\
\hline
\end{tabular}

At least 2 hours after the morning meal, all patients were acclimatised to the treadmill test before undergoing an incremental exercise test to his or her maximum ability. After a rest period of 2 hours, two or three 5-minute submaximal exercise levels (less than $80 \%$ of the maximum determined level) were performed to determine heart rate (HR) and oxygen consumption $\left(\dot{\mathrm{VO}}_{2}\right)$ under steady-state conditions. Others have shown that the $\mathrm{HR}-\dot{\mathrm{VO}}_{2}$ relation is linear over approximately 80 per cent of the plot, and that near maximal exercise the maximum heart rate is approached asymptotically (Davis, 1968). The submaximal levels were selected to provide the linear portion of the $\mathrm{HR}-\mathrm{VOO}_{2}$ relation.

During the last minute of each exercise level, the patient breathed into a low resistance valve (modified Otis-McKerrow, Warren E. Collins, Inc.) connected to a T-shaped stopcock to a 120 litre neoprene weather balloon (Warren E. Collins, Inc.). Within 20 minutes of expired air collection the balloon gas was analysed for percentage oxygen and carbon dioxide by mass spectrometer (MGA-1100 Series, Perin-Elmer Corp.) and gas volumes were measured in a Tissot spirometer. Volumes were corrected to STPD conditions and expressed as litres. Oxygen consumption and carbon dioxide production were calculated from standard formulae (Consolazio et al., 1951) and expressed as litres per minute per kilogram.

Means, standard error, and standard deviations of resting heart rate, heart rate at maximum exercise $\left(\mathrm{HR}_{\max }\right)$, and $\dot{\mathrm{V}} \mathrm{O}_{2} / \mathrm{kg}$ at maximum exercise $\left(\mathrm{VO}_{2 \max }\right)$ were calculated for each group. In this study, $\dot{\mathrm{V}} \mathrm{O}_{2 \max }$ was defined as the oxygen consumption during the last minute of the highest stage of the Bruce tests which was completed by a patient. Comparison was made between groups by the Student's $t$ test. The slope of the $\mathrm{HR}-\mathrm{VOO}_{2}$ relation was determined for each patient using the submaximal steady-state values. The slope for each patient was expressed as $\Delta$ heart rate $/ \Delta \mathrm{ml} \mathrm{VO_{2 }} / \mathrm{kg}$. Group means for this slope were determined and comparison between groups was made using the Student's t test.

\section{Results}

The values of each patient are shown in Table 3.

ELECTROCARDIOGRAPHIC ABNORMALITIES

One patient in group A (case 7) had ST-T changes which could be interpreted as a positive electrocardiographic stress test. Otherwise, all subjects had negative electrocardiographic stress tests for myocardial ischaemia. Four patients had cardiac arrhythmias at some point during the test; 3 were in group $A$ and the fourth was in group $C$. The arrhythmias were transient and all occurred either in the control period before exercise or during the recovery period after exercise. One group A patient (case 4) had frequent premature atrial contractions at rest which disappeared with exercise but reappeared in the recovery period followed by atrial flutter with a ventricular rate of 150 beats $/ \mathrm{min}$. Another group A patient (case 2) and a group C patient (case 19) had frequent premature atrial contractions in the recovery period after exercise.

\section{OXYGEN CONSUMPTION}

The oxygen consumption at maximal exercise $\left(\dot{\mathrm{V}} \mathrm{O}_{2 \mathrm{max}}\right)$ in group A patients was not significantly different from that in group B patients (Fig. 1). $\dot{\mathrm{V}} \mathrm{O}_{2 \max }$ in group $\mathrm{C}$ patients was significantly higher than in group B and group A patients.

All patients crossed the anaerobic threshold as determined by a respiratory exchange ratio $\left(\dot{\mathrm{V} C O}_{2} / \dot{\mathrm{VO}}_{2}\right)$ at maximum exercise closely approximating or greater than unity.

HEART RATE AT REST AND DURING EXERCISE Group A patients had a significantly slower heart rate at rest $(54.4$ beats $/ \mathrm{min})$ than both group $B$ $(85.4$ beats $/ \mathrm{min}, P<0.001)$ and group $C$ subjects (73.1 beats/min, $P<0.005)$. The group $C$ subjects had a higher than expected resting heart rate. This was probably because they were anxious about their exercise performance. Their resting heart rates were usually $\leqq 50$ beats per minute. At maximal exercise, the heart rate in group A patients was still significantly lower than in group B and group C subjects (Fig. 2).

Fig. 3 shows the heart rates for each group at measured oxygen consumption equivalent to 4 mets (four times the resting $\dot{\mathrm{VO}}_{2}$ ) which is also the $\mathrm{VO}_{2}$ needed to complete Stage I of the Bruce exercise procedure ( $1.7 \mathrm{mph}, 10 \%$ grade for 3 minutes). The latter $\dot{\mathrm{VO}}_{2}$ was calculated from the regression equations determined by Bruce for normal men $(17.2 \mathrm{ml} / \mathrm{kg}$ per $\mathrm{min})$ and normal women $(16.2$ $\mathrm{ml} / \mathrm{kg}$ per min). Patients with sick sinus syndrome (group A) had a significantly lower heart rate than 
Table 3 Results of exercise test in all 3 groups of patients

\begin{tabular}{|c|c|c|c|c|c|c|c|c|}
\hline & \multirow[t]{2}{*}{ Case no. } & \multirow[t]{2}{*}{ Age } & \multirow{2}{*}{$\begin{array}{l}\text { Weight } \\
(\mathrm{kg})\end{array}$} & \multirow{2}{*}{$\begin{array}{l}\text { Surface area } \\
\left(m^{2}\right)\end{array}$} & \multirow{2}{*}{$\begin{array}{l}\dot{V} O_{2 \max } \\
(m l / \min \text { per } k g)\end{array}$} & \multicolumn{2}{|l|}{ Heart rate } & \multirow{2}{*}{$\begin{array}{l}\text { Slope of } H R-\dot{V} O_{2} \\
\text { relation } \Delta H R / \Delta \dot{V} O_{2} \\
\text { (beats } / \text { min per } \mathrm{ml} \text { per } \\
\text { min per } \mathrm{kg} \text { ) }\end{array}$} \\
\hline & & & & & & $\begin{array}{l}\text { Rest } \\
\text { (beats/min) }\end{array}$ & $\begin{array}{l}\text { Max. } \\
\text { exercise } \\
\text { (beats/min) }\end{array}$ & \\
\hline Group $A$ & $\begin{array}{l}1 \\
2 \\
3 \\
4 \\
5 \\
6 \\
7\end{array}$ & $\begin{array}{l}62 \\
51 \\
61 \\
26 \\
53 \\
61 \\
60\end{array}$ & $\begin{array}{l}85 \cdot 7 \\
60 \cdot 0 \\
93 \cdot 2 \\
77 \cdot 7 \\
57 \cdot 0 \\
78 \cdot 2 \\
90 \cdot 0\end{array}$ & $\begin{array}{l}1.81 \\
1.61 \\
2.00 \\
1.93 \\
1.78 \\
1.89 \\
2.05\end{array}$ & $\begin{array}{l}11 \cdot 54 \\
17 \cdot 25 \\
20 \cdot 49 \\
50 \cdot 44 \\
19 \cdot 77 \\
20 \cdot 94 \\
26 \cdot 20\end{array}$ & $\begin{array}{l}68 \star \\
44 \\
54 \\
54 \\
44 \\
57 \\
60\end{array}$ & $\begin{array}{r}118 \\
94 \\
120 \\
160 \\
105 \\
122 \\
150\end{array}$ & $\begin{array}{l}3 \cdot 70 \\
4 \cdot 01 \\
2 \cdot 65 \\
2 \cdot 20 \\
3 \cdot 01 \\
3 \cdot 63 \\
2 \cdot 47\end{array}$ \\
\hline $\begin{array}{l}\text { Mean } \\
\text { SD } \\
\text { SEM }\end{array}$ & & $\begin{array}{r}53 \cdot 4 \\
12 \cdot 8 \\
4 \cdot 8\end{array}$ & $\begin{array}{r}77 \cdot 4 \\
14 \cdot 1 \\
5 \cdot 3\end{array}$ & $\begin{array}{l}1 \cdot 86 \\
0 \cdot 15 \\
0.06\end{array}$ & $\begin{array}{r}23 \cdot 8 \\
12 \cdot 5 \\
4 \cdot 7\end{array}$ & $\begin{array}{r}54 \cdot 4 \\
8 \cdot 6 \\
3 \cdot 2\end{array}$ & $\begin{array}{r}124 \cdot 1 \\
23 \cdot 4 \\
8 \cdot 9\end{array}$ & $\begin{array}{l}3 \cdot 10 \\
0.69 \\
0.26\end{array}$ \\
\hline Group $B$ & $\begin{array}{r}8 \\
9 \\
10 \\
11 \\
12 \\
13 \\
14\end{array}$ & $\begin{array}{l}62 \\
57 \\
54 \\
50 \\
51 \\
53 \\
65\end{array}$ & $\begin{array}{r}68.6 \\
80.9 \\
80.9 \\
93.2 \\
112.7 \\
64.6 \\
94.5\end{array}$ & $\begin{array}{l}1.62 \\
2.01 \\
1.99 \\
1.94 \\
2 \cdot 18 \\
1.72 \\
2.06\end{array}$ & $\begin{array}{l}19 \cdot 93 \\
23 \cdot 68 \\
20 \cdot 35 \\
19 \cdot 72 \\
17 \cdot 35 \\
17 \cdot 65 \\
20 \cdot 87\end{array}$ & $\begin{array}{l}79 \\
92 \\
97 \\
83 \\
77 \\
86 \\
84\end{array}$ & $\begin{array}{l}167 \\
174 \\
177 \\
158 \\
150 \\
158 \\
158\end{array}$ & $\begin{array}{l}6 \cdot 76 \\
4 \cdot 38 \\
5 \cdot 10 \\
4 \cdot 88 \\
6 \cdot 05 \\
4 \cdot 37 \\
4 \cdot 87\end{array}$ \\
\hline $\begin{array}{l}\text { Mean } \\
\text { SD } \\
\text { SEM }\end{array}$ & & $\begin{array}{r}56 \cdot 0 \\
5 \cdot 7 \\
2 \cdot 1\end{array}$ & $\begin{array}{r}85 \cdot 1 \\
16 \cdot 6 \\
6 \cdot 3\end{array}$ & $\begin{array}{l}1.93 \\
0.20 \\
0.07\end{array}$ & $\begin{array}{r}19.93 \\
2.12 \\
0.80\end{array}$ & $\begin{array}{r}85 \cdot 4 \\
7 \cdot 0 \\
2 \cdot 7\end{array}$ & $\begin{array}{r}163 \cdot 1 \\
9 \cdot 8 \\
3 \cdot 7\end{array}$ & $\begin{array}{l}5 \cdot 20 \\
0 \cdot 88 \\
0 \cdot 33\end{array}$ \\
\hline Group $C$ & $\begin{array}{l}15 \\
16 \\
17 \\
18 \\
19 \\
20 \\
21\end{array}$ & $\begin{array}{l}29 \\
35 \\
32 \\
32 \\
47 \\
30 \\
29\end{array}$ & $\begin{array}{l}68 \cdot 2 \\
81 \cdot 8 \\
77 \cdot 3 \\
75 \cdot 0 \\
65 \cdot 0 \\
56 \cdot 8 \\
49 \cdot 0\end{array}$ & $\begin{array}{l}1.85 \\
1.75 \\
1.95 \\
1.88 \\
1.77 \\
1.63 \\
1.50\end{array}$ & $\begin{array}{l}48 \cdot 53 \\
44 \cdot 97 \\
59 \cdot 60 \\
54 \cdot 86 \\
50 \cdot 87 \\
61 \cdot 87 \\
50 \cdot 39\end{array}$ & $\begin{array}{l}70 \\
65 \\
55 \\
90 \\
74 \\
75 \\
83\end{array}$ & $\begin{array}{l}188 \\
188 \\
174 \\
188 \\
188 \\
195 \\
190\end{array}$ & $\begin{array}{l}3.35 \\
2.91 \\
1.90 \\
1.42 \\
2.19 \\
3.87 \\
1.88\end{array}$ \\
\hline $\begin{array}{l}\text { Mean } \\
\text { SD } \\
\text { SEM }\end{array}$ & & $\begin{array}{r}33 \cdot 4 \\
6 \cdot 3 \\
2 \cdot 4\end{array}$ & $\begin{array}{r}67 \cdot 6 \\
11 \cdot 7 \\
4 \cdot 4\end{array}$ & $\begin{array}{l}1 \cdot 76 \\
0 \cdot 15 \\
0 \cdot 06\end{array}$ & $\begin{array}{r}53 \cdot 00 \\
6 \cdot 07 \\
2 \cdot 30\end{array}$ & $\begin{array}{r}73 \cdot 1 \\
11 \cdot 5 \\
4 \cdot 3\end{array}$ & $\begin{array}{r}187 \cdot 3 \\
6 \cdot 4 \\
2 \cdot 4\end{array}$ & $\begin{array}{l}2 \cdot 50 \\
0.89 \\
0.34\end{array}$ \\
\hline$\star$ Paced rat & & & $P$ values: & $\begin{array}{l}A \text { vs } B \\
A \text { vs } C \\
B \text { vs } C\end{array}$ & $\begin{array}{l}>0.5 \\
<0.001 \\
<0.001\end{array}$ & $\begin{array}{l}<0.001 \\
<0.005 \\
<0.05\end{array}$ & $\begin{array}{l}<0.005 \\
<0.001 \\
<0.001\end{array}$ & $\begin{array}{l}<0.001 \\
=0.2 \\
<0.001\end{array}$ \\
\hline
\end{tabular}

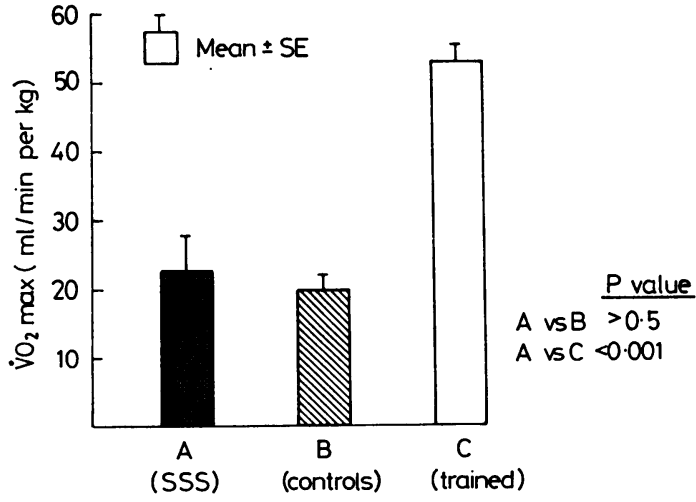

Fig. 1 Oxygen consumption at the maximum level of exercise $\left(\dot{V} \mathrm{O}_{2 \max } / \mathrm{kg}\right.$ ) for the 3 groups of patients. Graph shows mean $\pm S E M$ for each group.

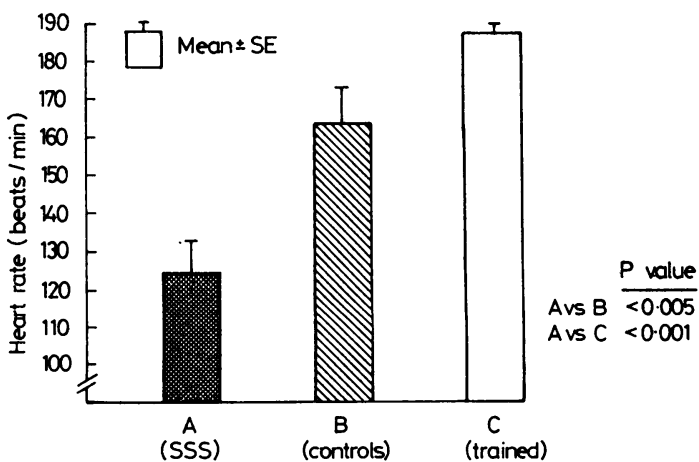

Fig. 2 Heart rate at the maximum level of exercise $\left(H R_{\max }\right)$ for the 3 groups. Graph shows group mean $\pm S E M$. 


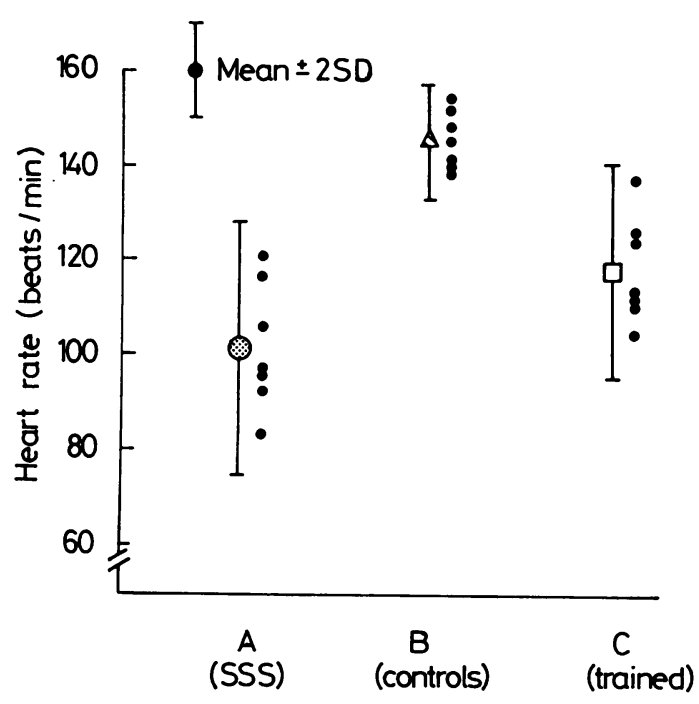

Fig. 3 Heart rate at the oxygen consumption needed to finish the third minute of the Bruce exercise procedure (see text). Group mean $\pm 2 S D$ are shown along with the individual data points for all patients in each group. The upper limit of group $A$ is lower than the lower limit of group $B$ indicating the clear separation of these 2 groups.

'age-matched' controls (group B). The 95 per cent confidence limits for groups A and B were clearly separated (upper limit for group A was 128.5 beats/min and lower limit of group $B$ was 134.4 beats/min). Group A patients could not be separated from trained volunteers (group C).

\section{HEART RATE-OXYGEN CONSUMPTION RELATION}

The mean slope of group A patients $(3.1 \pm 0.26$ $\Delta \mathrm{HR} / \Delta \mathrm{VO}_{2}$ per $\mathrm{kg}$ ) was significantly less than that of group B patients $\left(5 \cdot 2 \pm 0.33 \Delta \mathrm{HR} / \Delta \dot{\mathrm{VO}}_{2}\right.$ per $\mathrm{kg}$ ) but was not significantly different from that of group $\mathrm{C}$ subjects.

\section{Discussion}

When compared with an 'age-matched' control group, our patients with sick sinus syndrome had a reduced heart rate response to exercise characterised by a lower heart rate at maximum exercise and a reduced rate of change of heart rate as the level of exercise increased. Since the patients with sick sinus syndrome reached the same level of oxygen consumption at maximum exercise as the 'agematched' controls, the chronotropic response to the stimulus of exercise was obviously reduced in sick sinus syndrome. Not unexpectedly, the patients with sick sinus syndrome reached a much lower level of maximum oxygen consumption ( $\dot{\mathrm{V}}_{2 \max }$ ) as compared with trained subjects. However, it is interesting that the patients with sick sinus syndrome had a rate of change of heart rate with increases in oxygen consumption similar to that of the trained subjects.

The patients with sick sinus syndrome in our study reached the same level of maximal oxygen consumption ( $\left.\dot{\mathrm{V}}_{2 \text { max }}\right)$ as 'age-matched' controls. At first glance this is surprising. Sick sinus syndrome is often associated with underlying heart disease but in others may be the result of primary disease of the specialised pacemaker and conducting tissues, that is the sinoatrial node, atrioventricular node, and the subjunctional tissues (Ferrer, 1968; Rosen et al., 1971; Rubenstein et al., 1972; Ferrer, 1973; Kaplan et al., 1973). Associated disease of the atrial muscle may be present in these patients (Thery et al., 1977). Recently, Abbott and coworkers (1977) have published their results with graded exercise testing in 16 patients with sinus node dysfunction. Similar to our patients, their patients were unable to achieve maximum heart rates comparable with age- and sex-matched control subjects. However, their patients were also unable to achieve maximum $\dot{\mathrm{VO}}_{2}$ compared with controls, which is different from our findings. This difference may partly beaccounted for by the presence of 'clinical evidence of myocardial disease' in 8 of their 16 patients. Only 2 of our 7 patients had mild forms of other heart disease and no patient complained of dyspnoea or exercise intolerance; therefore, their ability to match $\dot{\mathrm{VO}}_{2 \max }$ with controls is easy to understand. It is fortunate that our patients with sick sinus syndrome did not have significant underlying heart disease, because it allowed us to evaluate the response of the sinoatrial node which was not limited by associated heart disease. Patients with underlying heart disease have a different response to exercise (see below) and are known to have a defective cardiac parasympathetic control (Eckberg et al., 1971).

The circulatory system in normal man responds to exercise with increases in cardiac output in proportion to the amount of work being done (as measured by oxygen consumption) (Åstrand and Rodahl, 1970). The response of the heart is an integrated effect of tachycardia, sympathetic stimulation, and utilisation of the Frank-Starling mechanism (Braunwald et al., 1976). Tachycardia plays an important role in allowing the heart to meet the demand of an increased cardiac output. In the upright posture, the increase in cardiac output at lower levels of exercise is accomplished by increases in stroke volume, and in heart rate (Chapman et al., 1960; Wang et al., 1960). However, at greater work 
levels the increase in stroke volume levels off (or increases only slightly) and the needed increment in cardiac output is provided mainly by an increase in heart rate (Åstrand et al., 1964; Epstein et al., 1967). Near maximal exercise, the heart rate increase is slowed as the maximum heart rate is approached (Davis, 1968). Thus, the heart rateoxygen consumption relation is linear up to near maximum oxygen consumption after which time the subject's age-related maximum heart rate is reached asymptotically. The physiological mechanisms involved in the heart rate response to exercise are complex, but for the most part are mediated through the autonomic nervous system such that exercise increases the sympathetic and decreases the parasympathetic efferent stimuli to the heart (Robinson et al., 1966). Mechanical factors such as distention of the right atrium by increased venous return (Bainbridge reflex) may also be contributory (Folkow and Neil, 1971). Training is associated with a lower heart rate at rest and a decreased rate of change of heart rate as exercise increases, so that at a given work load the trained subject will have a lower heart rate in comparison with his untrained counterpart ( $\AA$ strand et al., 1964). In addition, the trained subject develops myocardial hypertrophy and increased end-diastolic ventricular volume (Morganroth et al., 1975), both of which provide the myocardial reserve that enables the trained subject to maintain a normal cardiac output in the face of bradycardia.

In contrast to normal subjects, patients with impaired cardiac function have a limited ability to increase stroke volume with exercise, and in fact the stroke volume may even decrease as exercise increases (Epstein et al., 1967). Under these circumstances the ability to increase heart rate and provide the needed increment in cardiac output is very important. Therefore, in general, patients with significant heart disease have a higher heart rate for a given work load than a normal subject. Ellestad (1975) has described an apparent exception to this point in a subgroup of patients with ischaemic heart disease who show an inappropriately low heart rate increase with exercise, a pattern he considers a poor prognostic sign. Hinkle and his colleagues (1972) found that middle-aged or older men with low mean heart rates and a low heart rate response to exercise had a higher than expected rate of sudden death. It is also known that the 'intrinsic heart rate', the heart rate after both sympathetic and parasympathetic nervous systems blockade, is lower in patients with heart disease (Jose and Taylor, 1969; Jose and Collison, 1970). Since it is also known that the sick sinus syndrome is associated with a variety of types of heart disease, it is possible that some patients cited by Ellestad and Hinkle may have had mild forms of the sick sinus syndrome.

Clinically, patients with sick sinus syndrome are characterised by bradycardia or bradyarrhythmia caused by sinus node dysfunction which results in abnormalities of initiation or of exit of the pacemaker impulse. Our data show that in response to exercise the patients with sick sinus syndrome have a rate of change of heart rate (slope of the $\mathrm{HR}-\mathrm{V}_{2}$ relation) that is similar to that of younger, trained subjects. Yet, the maximum level of exercise attained by our patients with sick sinus syndrome was the same as that attained by 'age-matched' controls suggesting that the patients with sick sinus syndrome may have circulatory adaptations similar to those seen with training, that is increase in stroke volume with exercise, widening of the arteriovenous oxygen difference, or increased efficiency of distribution of cardiac output to the exercising muscles in addition to the cardiac changes previously mentioned. Ross and co-workers (1965) have shown that when the ability to vary the ventricular rate is impaired, as in atrioventricular block or during atrial pacing at a constant rate, the changes in cardiac output are modulated primarily through changes in stroke volume. A similar situation is known to exist after surgical denervation of the heart (Donald and Shepherd, 1963). The sick sinus syndrome may be analogous to both of these examples. Stated another way, the patient with sick sinus syndrome without significant associated heart disease may be using circulatory adaptations similar to those of the trained state in order to maintain exercise capacity in the face of an inability to increase heart rate to an appropriate level.

\section{CLINICAL IMPLICATIONS}

In the clinical evaluation of patients with sick sinus syndrome it is important that the patient's heart rate be considered in the context of the entire clinical picture (Consolazio et al., 1951; Ferrer, 1968; Rosen et al., 1971; Ferrer, 1973; Kaplan et al., 1973). For example, a heart rate of 75 beats $/ \mathrm{min}$ in the face of high fever is not appropriate and should suggest the possibility of sinoatrial node disease. The abnormality could be even more subtle and the diagnosis of sick sinus syndrome may be difficult. Of the methods available to assess sinoatrial node function the most frequently used are pharmacological provocation tests with atropine and isoprenaline, and electrophysiological studies such as the sinus node recovery time (Ferrer, 1968; Rosen et al., 1971; Mandel et al., 1972; Dhingra et al., 1973; Ferrer, 1973; Kaplan et al., 1973; Strauss et al., 1973; Mandel et al., 1975), and secondary pauses after termination of rapid atrial pacing 
(Benditt et al., 1976). However, these tests are often equivocal because of the considerable overlap between results obtained in normal subjects and patients with the sick sinus syndrome. Holter monitoring may also be of use in documenting the sick sinus syndrome but, again, the findings may be normal despite the presence of sick sinus syndrome. Thus, there is a need for other ways to evaluate this group of patients.

The use of exercise to test the response of the sinoatrial node has been suggested by other authors. Ferrer suggested that rapid arm or leg flexion might be used to assess the sinoatrial node response to exercise (Ferrer, 1973). Erant and Shaw exercised 27 patients with 'lazy sinus syndrome' and found an 'abnormally small' increase in sinus rate (Erant and Shaw, 1971). Mandel et al. assessed the sinoatrial node response to treadmill exercise in 14 patients, all of whom had increases in heart rate deemed appropriate for the degree of exercise being done but which was not quantified (Mandel et al., 1972). On the other hand, our findings show that when the treadmill exercise load is quantified by measurements of oxygen consumption the patients with sick sinus syndrome without associated underlying heart disease do not have the heart rate response of the 'age-matched' control subjects.

Since oxygen consumption determinations are cumbersome for routine clinical practice and are not readily available, we have examined our data in order to obtain a simple heart rate work load relation that might distinguish the patients with sick sinus syndrome. Bruce has quantified the oxygen consumption needed at each of the incremental levels of his exercise procedure. In the third minute of Stage $I$ of his procedure the estimated oxygen consumption calculated from Bruce's regression equation is $16.2 \mathrm{ml} / \mathrm{kg}$ per min for normal women and $17.2 \mathrm{ml} / \mathrm{kg}$ per min for normal men (Bruce et al., 1973).

None of our patients with sick sinus syndrome achieved a heart rate greater than 120 beats $/ \mathrm{min}$ at these levels of measured oxygen consumption and the 95 per cent confidence upper level for patients with sick sinus syndrome was 128.5 beats/min (see Fig. 3). On the other hand, the 'age-matched' 'normal' subjects had higher heart rates at the same oxygen consumption. The trained subjects could not be separated from the patients with sick sinus syndrome at this low level of exercise, but the trained subjects ultimately achieved a much greater maximum oxygen consumqtion. Our data show that if a patient with suspected sick sinus syndrome who does not have significant associated heart disease reaches the end of the third minute of the first stage of the Bruce procedure and has a heart rate greater than 130 beats per minute, then it is unlikely that such a patient has sick sinus syndrome. However, the diagnostic value of these observations needs to be prospectively evaluated.

\section{References}

Abbott, J. A., Hirshfeld, D. S., Kunkel, F. W., and Scheinman, M. M. (1977). Graded exercise testing in patients with sinus node dysfunction. American fournal of Medicine, 62, 330-338.

Åstrand, P-O., Cuddy, T., Saltin, B., and Stenberg, J. (1964). Cardiac output during submaximal amd maximal work. Fournal of Applied Physiology, 19, 268-274.

Asstrand, P-O., and Rodahl, K. (1970). Textbook of Work Physiology, pp. 157-158. McGraw-Hill, New York.

Benditt, D. F., Strauss, H. C., Scheinman, M. M., Behar, V. S., and Wallace, A. G. (1976). Analysis of secondary pauses following termination of rapid atrial pacing in man. Circulation, 54, 436-441.

Braunwald, E., Ross, J., Jr., and Sonnenblick, E. (1976). Mechanisms of Contraction of the Normal and Failing Heart, pp. 292-308. Little Brown, Boston.

Bruce, R. A., Kusmi, F., and Hosmer, D. (1973). Maximal oxygen intake and nomographic assessment of functional aerobic impairment in cardiovascular disease. American Heart fournal, 85, 546-562.

Chapman, C. B., Fisher, J. N., and Sproule, B. J. (1960). Behavior of stroke volume at rest and during exercise in human beings. Fournal of Clinical Investigation, 39, 1208-1213.

Consolazio, C., Johnson, R., and Marek, E. (1951). Metabolic Methods, pp. 333-337. C. V. Mosby, St. Louis.

Davis, C. T. M. (1968). Limitations to the prediction of maximum oxygen intake from cardiac frequency measurements. Fournal of Applied Physiology, 24, 700-706.

Dhingra, R. C., Rosen, K. M., and Rahimtoola, S. H. (1973). Normal conduction intervals and responses in 61 patients using His bundle recording and atrial pacing. Chest, 64, 55-59.

Donald, D. E., and Shepherd, J. T. (1963). Response to exercise in dogs with cardiac denervation. American fournal of Physiology, 205, 393-400.

Eckberg, D. L., Drabinsky, M., and Braunwald, E. (1971). Defective cardiac parasympathetic control in patients with heart disease. New England fournal of Medicine, 285, 877-883.

Ellestad, M. (1975). Stress Testing, pp. 37-40. F. A. Davis, Philadelphia.

Epstein, S. E., Beiser, G. D., Stampfer, M., Robinson, B. F., and Braunwald, E. (1967). Characterization of the circulatory response to maximal upright exercise in normal subjects and patients with heart disease. Circulation, 35, 1049-1062.

Erant, D., and Shaw, D. B. (1971). Sinus bradycardia. British Heart fournal, 33, 742-749.

Ferrer, M. I. (1968). The sick sinus syndrome in atrial disease. Fournal of the American Medical Association, 206, 645-646.

Ferrer, M. I. (1973). The sick sinus syndrome. Circulation, 47, 635-641.

Folkow, B., and Neil, E. (1971). Circulation, pp. 187-188. Oxford University Press, New York.

Hinkle, L. E., Jr., Carver, S. T., and Plakun, A. (1972). Slow heart rates and increased risk of cardiac death in middle aged men. Archives of Internal Medicine, 129, 732-748.

Jose, A. D., and Collison, D. (1970). The normal range and determinants of the intrinsic heart rate in man. Cardiovascular Research, 4, 160-167. 
Jose, A. D., and Taylor, R. R. (1969). Autonomic blockage by propranolol and atropine to study intrinsic myocardial function in man. Fournal of Clinical Investigation, 48, 2019-2031.

Kaplan, B. M., Langendorf, R., Lev, M., and Pick, A. (1973). Tachycardia-bradycardia syndrome (so-called 'sick sinus syndrome'). American fournal of Cardiology, 31, 497-508.

Mandel, W. J., Hayakawa, H., Allen, H. N., Danzig, R., and Kermaier, A. I. (1972). Assessment of sinus node function in patients with the sick sinus syndrome. Circulation, 46, 761-769.

Mandel, W. J., Laks, M. M., and Obayashi, K. (1975). Sinus node function. Archives of Internal Medicine, 135, 388-394.

Morganroth, J., Maron, B. J., Henry, W. L., and Epstein, S. E. (1975). Comparative left ventricular dimensions in trained athletes. Annals of Internal Medicine, 82, 521-524.

National Council of the Y.M.C.A. (1975). YMCAardiac therapy: A program of medically prescribed treatment and supervised exercise for coronary patients.

New York Heart Association, Criteria Committee (1973). Disease of the Heart and Blood Vessels: Nomenclature and Criteria for Diagnosis, pp. 80-81. Little, Brown, Boston.

Robinson, B. F., Epstein, S. E., Beiser, G. D., and Braunwald, E. (1966). Control of heart rate by the autonomic nervous system. Studies in man on interrelation between baroreceptor mechanisms and exercise. Circulation Research, 19, 400-411.

Rosen, K. M., Loeb, H. S., Sinno, M. Z., Rahimtoola, S. H., and Gunnar, R. M. (1971). Cardiac conduction in patients with symptomatic sinus node disease. Circulation, 43, 836-844.

Ross, J. J., Jr., Linhart, J. W., and Braunwald, E. (1965). Effects of changing heart rate in man by electrical stimulation of the right atrium. Circulation, 32, 549-558.

Rubenstein, J. J., Schulman, C. L., Yurchak, P. M., and DeSantis, R. W. (1972). Clinical spectrum of the sick sinus syndrome. Circulation, 46, 5-13.

Short, D. S. (1954). The syndrome of alternating bradycardia and tachycardia. British Heart Fournal, 16, 208-214.

Strauss, H. C., Saroff, A. L., Bigger, J. T., Jr., and Giardina, E. G. V. (1973). Premature atrial stimulation as a key to the understanding of sinoatrial conduction in man. Presentation of the data and critical review of the literature. Circulation, 47, 86-93.

Thery, C., Gosselin, B., Lekieffre, J., and Warembourg, H. (1977). Pathology of sino-atrial node. Correlations with electrocardiographic findings in 111 patients. American Heart fournal, 93, 735-740.

Wang, Y., Marshall, R. J., and Shepherd, J. T. (1960). The effect of changes in posture and of graded exercise on stroke volume in man. Fournal of Clinical Investigation, 39, 1051-1061.

Requests for reprints to Professor Shahbudin $\mathrm{H}$. Rahimtoola, Division of Cardiology, University of Oregon Health Sciences Center, 3181 S.W. Sam Jackson Park Road, Portland, Oregon 97201, U.S.A. 